\title{
MUTATION OF katG IN A CLINICAL ISOLATE OF Mycobacterium tuberculosis: EFFECTS ON CATALASE-PEROXIDASE FOR ISONIAZID ACTIVATION
}

\author{
PURKAN $N^{1}$ IHSANAWATI', D. NATALIA', Y. M. SYAH', \\ D. S. RETNONINGRUM $M^{3}$, H. S. KUSUMA

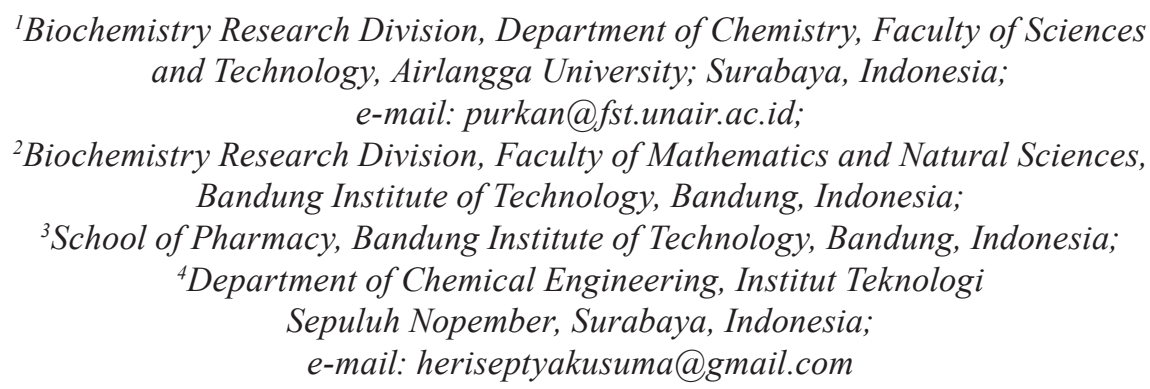

Mutations in katG gene are often associated with isoniazid (INH) resistance in Mycobacterium tuberculosis strain. This research was perfomed to identify the katG mutation in clinical isolate (L8) that is resistant to INH at $1 \mu \mathrm{g} / \mathrm{ml}$. In addition to characterize the catalase-peroxidase of Kat $G \mathrm{~L} 8$ and perform the ab initio structural study of the protein to get a more complete understanding in drug activation and the resistance mechanism. The kat G gene was cloned and expressed in Escherichia coli, then followed by characterization of catalase-peroxidase of KatG. The structure modelling was performed to know a basis of alterations in enzyme activity. A substitution of A713G that correspond to Asn238Ser replacement was found in the L8 $k a t G$. The Asn238Ser modification leads to a decline in the activity of catalase-peroxidase and INH oxidation of the $L 8 \mathrm{Kat} G$ protein. The catalytic efficiency $\left(K_{c a} / K_{M}\right)$ of mutant $\mathrm{Kat}_{\text {Asn238ser }}$ respectively decreases to 41 and $52 \%$ for catalase and peroxidase. The mutant Kat $G_{\text {Asn238Ser }}$ also shows a decrease of $62 \%$ in INH oxidation if compared to a wild type KatG (KatGwt). The mutant Asn238Ser might cause instability in the substrate binding site of $K a t G$, because of removal of a salt bridge connecting the amine group of Asn238 to the carboxyl group of Glu233, which presents in KatGwt. The lost of the salt bridge in the substrate binding site in mutant $K a t G_{\text {Asn238Ser }}$ created changes unfavorable for enzyme activities, which in turn emerge as INH resistance in the L8 isolate of M. tuberculosis.

Key words: Mycobacterium tuberculosis, INH resistance, katG, catalase-peroxidase.

$\mathrm{T}$ uberculosis (TB) is well known as an infectious disease that is caused by Mycobacterium tuberculosis. The disease is currently ranked as the seventh most common causes of death in the world, and still estimated to remain in the top 10 causes of death untill 2030. Recently, TB is reported as the second leading cause of death in adults and recorded as the deadliest of all infectious diseases. Indonesia is classified as a country with the large number of TB cases and occupies the fifth rank of the 22 countries with high potential of TB. In the country, there are about 500,000 new cases of TB annually and 175,000 of them are deaths $[1,2]$. Two percent of new cases and twelve percent of the recurring cases of TB found in Indonesia are the multid- rug-resistant (MDR) cases [1]. A better understanding in the antituberculous drug resistance is needed to make easy in the TB therapy.

Isoniazid (isonicotinic acid hydrazide; INH) has commonly been recommended by the World Health Organization (WHO) to treat tuberculosis since 1952 because the drug has a high bactericidal effect and a low price [3]. The bactericidal effect of INH as TB drug depends on catalase-peroxidase of M. tuberculosis which is encoded by kat $G$ gene. The enzyme plays a role to convert isoniazid absorbed by the M. tuberculosis to be in active form, an isonicotinoyl acyl radical, to trigger the death of mycobacteria. This might occur because an isonicotinoyl acyl radical is a potential inhibitor for enoyl-acyl 
carrier protein reductase (InhA) and $\beta$-ketoacyl-acyl carrier protein synthase (KasA), the two key enzymes for the biosynthesis of mycolic acids, a cell wall component of mycobacteria $[4,5]$.

KatG mediates the sensitivity of M. tuberculosis to INH. The kat G deficiency strain of M. tuberculosis, which is resistant to INH, can restore the sensitivity to INH when it is complemented with a functional $k a t G$ [6]. Meanwhile, total deletion of kat $G$ gene in $M$. tuberculosis raised resistance to INH [6-8]. Nevertheless, the loss of catalase-peroxidase in M. tuberculosis has not yet explained completely the mechanism of INH resistance, because the total deletion of $k a t G$ is rarely found in clinical isolates $[4,9]$.

It has been reported that $50-70 \%$ of INH-resistant $M$. tuberculosis strains are associated with the mutation in the $k a t G$ gene [3, 4]. The mutation types are very diverse, with missense mutations being the most common alteration. The mutations in $k a t G$ also reveal unique types in INH resistant strain from different geographical areas. The frequency of mutation types in $k a t G$ is often only associated with drug resistance and rarely linked directly to the change of INH sensitivity or to the effect of the enzymatic activity of KatG. The kat $G$ mutations that affect catalase-peroxidase activity have been found in either all part of the gene and encode the N-terminal or the C-terminal part of the protein $[10,5]$. Many variants of KatG associated with INH resistance exhibits a decrease in catalase-peroxidase activities. The decreasing scale of the activity among the mutants of $k a t G$ does not directly correlate with INH resistance [11, 12]. This is the basis of the argument that the INH resistance in clinical isolates is not linked directly to the ability of variants of KatG in INH activation.

The mutant KatG Ser315Thr, that is commonly found in clinical isolates and associated with INH resistance, decreases the activities of catalase-peroxidase and INH oxidation [13, 14]. The amino acid Ser315 in KatG is closely put in the active environment. So that, the genetic modifications in this part are easily understood as the producer of importantly affected enzymatic function and thus isoniazid resistance. As many as $50 \%$ variants of kat $G$ associated with INH resistance are not modified in Ser315Thr. Biochemical analysis of variants of kat G other than Ser315Thr is necessary to examine the relation between INH resistance with the changes in the function and structure of the mutants.
Some clinical isolates of INH-resistant $M$. tuberculosis from Indonesian TB patients are not mutated at codon 315 of $\mathrm{katG}$. Among these isolates, an isolate, namely L8 isolate, shows resistance to INH at $1 \mu \mathrm{g} / \mathrm{ml}$. This paper shows the correlation of $\mathrm{katG}$ mutation in the isolate with the biochemical properties of catalase-peroxidase, especially for isoniazid oxidation. This paper also examines the ab initio structural study of the mutant KatG L8 with the aim of gaining a more complete understanding of drug activation and the resistance mechanism.

\section{Materials and Methods}

Bacterial strains and plasmids. A clinical isolate of M. tuberculosis was obtained from sputum of a TB patient in Bandung, Indonesia. Escherichia coli TOP10 (Invitrogen, Carlsbad, CA) was used as hosts for cloning of $k a t G$ of INH resistant and sensitive M. tuberculosis. The E. coli BL21 (DE3) (Promega, Madison, USA) was employed as an expression host of KatG. The plasmid pGEM $^{\circledR}-\mathrm{T}$ (Invitrogen) and pCold II-DNA (Kinki University) were used as a cloning and expression vector, respectively.

Preparation of chromosomal DNA. Chromosomal DNAs of $M$. tuberculosis of wild type and clinical isolates were prepared by an alkaline lysis method in $5 \mathrm{mM}$ Tris-Cl buffer ( $\mathrm{pH} 8.5$ ) containing $0.5 \%(\mathrm{~b} / \mathrm{v})$ Tween -20 and $0.2 \mathrm{mg} / \mathrm{ml}$ proteinase $\mathrm{K}$ at $50{ }^{\circ} \mathrm{C}$ for $60 \mathrm{~min}$. The mixture then was heated at $95{ }^{\circ} \mathrm{C}$ for $5 \mathrm{~min}$. Cellular debris was collected at $12,000 \mathrm{~g}$ for $10 \mathrm{~min}$ and the supernatant containing chromosomal DNA of $M$. tuberculosis was used for PCR [15].

Amplification of katG gene. The full length of the kat $G$ gene was amplified by the polymerase chain reaction (PCR) technique using FG and RG primers (Table 1). PCR was performed in a total reaction volume of $50 \mu \mathrm{l}$ containing $50 \mathrm{ng}$ cromosomal DNA; 1xPCR buffer $(20 \mathrm{mM}$ Tris$\mathrm{HCl} \mathrm{pH} \mathrm{8.4,} 50 \mathrm{mM} \mathrm{KCl}$ ); $0.1 \mathrm{mM}$ of each primer, $200 \mu \mathrm{M}$ dNTPs; $1.5 \mathrm{mM} \mathrm{MgCl}_{2}$; and 0.25 unit of Taq DNA polymerase (Amersham). The amplification process was done by a GeneAmp ${ }^{\circledR}$ PCR System 2700 (PerkinElmer), and set at the following steps: pre-denaturation at $94^{\circ} \mathrm{C}$ for $4 \mathrm{~min}, 25$ cycles of denaturation at $94{ }^{\circ} \mathrm{C}$ for $1 \mathrm{~min}$, annealing at $57{ }^{\circ} \mathrm{C}$ for $1 \mathrm{~min}$, and an extension at $72{ }^{\circ} \mathrm{C}$ for $3 \mathrm{~min}$. The process was terminated by post-elongation at $72{ }^{\circ} \mathrm{C}$ for $7 \mathrm{~min}$. All PCR products were analyzed using agarose gel electrophoresis and purified by GFX purification kit (Amersham). 
Table 1. The oligonucleotide primers for sequencing of kat $G$ gene

\begin{tabular}{l|l}
\hline $\begin{array}{c}\text { Name of } \\
\text { Primer }\end{array}$ & \multicolumn{1}{c}{$\begin{array}{c}\text { Nucleotide sequence } \\
\text { of primers }\left(5^{\prime} \rightarrow 3^{\prime}\right)\end{array}$} \\
\hline SP6 promoter & catacgatttaggtgacactatag \\
T7 promoter & taatacgactcactataggg \\
FG & gttattgaattcgatgccegagcaacacccac \\
RG & ttcatagcggccgcgcgcacgtcgaactgtc \\
KF & gcagatggggctgatctacg \\
FDPRK & cgacgagttcgccaaggc \\
\hline
\end{tabular}

Cloning of the $\boldsymbol{k a t} \boldsymbol{G}$ gene. The PCR products corresponding to the kat $G$ gene was inserted into pGEM ${ }^{\circledR}-\mathrm{T}$ vector, then the recombinant vector was used to transform $E$. coli TOP10 using the $\mathrm{CaCl}_{2}$ method. [16] Transformants were screened in Luria Bertani (LB) solid medium containing ampicillin $100 \mu \mathrm{g} / \mathrm{ml}$, 5-bromo-4-chloro-3-indolyl$\beta$-D-galacto-pyranoside (X-gal) and isopropyl $\beta$-Dthiogalactoside (IPTG). The target transformants which carried recombinant pGEM-T-kat $G$ plasmid were selected by a restriction analysis.

DNA sequencing. The nucleotide of the $k a t G$ gene in the recombinant plasmid was sequenced by an automatic nucleotide sequencer (ABI PRISM, Macrogen, Seoul, Korea). The recombinant pGEM $^{\mathbb{Q}}$-T, namely pGEM-T- $k a t G$ was used for DNA template. All oligonucleotides primers used for the sequencing were presented in Table 1.

Alignment analysis. The $k a t G$ genes of wild type and clinical isolate of $M$. tuberculosis were analyzed in silico by aligning the nucleotide sequences of the genes and their deduced amino acid sequences, using the SeqManTMII and MegAlignTM DNASTAR program (Lasergene). The nucleotides of the genes were also compared with $k a t G$ nucleotides in Genbank (accession number X68081).

Subcloning of the katG gene. The katG gene fragment in pGEM-T-kat $G$ was taken by digestion of plasmid recombinant with NdeII and XbaI. The digestion product was purified and inserted into plasmid pCold II DNA, which previously had been digested with the same restriction enzymes. The ligation product was transformed to $E$. coli BL21 $(D E 3)$ and the transformed bacteria were then grown on a selective LB agar plate.

KatG gene expression. A single colony of E. coli BL21 (DE3) containing recombinant plasmid (pCold II-katG) was cultured in LB liquid medium containing ampicillin $100 \mu \mathrm{g} / \mathrm{ml}$, then followed by shaking at $37^{\circ} \mathrm{C}$ to obtain an optical density (OD) at $\lambda 600 \mathrm{~nm}$ approximately of $0.4-0.5$. The culture was then immediately cooled at $15^{\circ} \mathrm{C}$ for 30 minutes without shaking. To induce the expression of recombinant protein, the culture was added by $0.1 \mathrm{mM}$ IPTG, and followed by shaking at $15{ }^{\circ} \mathrm{C}$ for $24 \mathrm{~h}$. The culture was then centrifugatedat $5,000 \mathrm{~g}$ for $10 \mathrm{~min}$ to harvest the cells. The resulted cells were washed and re-suspended in $50 \mathrm{mM}$ potassium phosphate buffer ( $\mathrm{pH}$ 7.0), and then disrupted by sonication. The cellular debris was removed by centrifugation at $12,000 \mathrm{~g}$ for $15 \mathrm{~min}$. The $\mathrm{KatG}$ protein that remained in the supernatant was then purified.

Protein purification. The recombinant protein of KatG was purified by affinity chromatography using HisTrapTM-HP column (GE Healthcare, Freiburg, Germany) containing Ni-sepharose matrix. The purification steps were run according to the manufacturer's protocol. The recombinant protein was eluted gradually by $50 \mathrm{mM}$ K-phosphate buffer, $\mathrm{pH} 7.0$, containing imidazole of $50-200 \mathrm{mM}$. The purified protein was analyzed by a sodium dodecyl sulphate-polyacrylamide gel electrophoresis (SDSPAGE).

Catalase-peroxidase activity and INH oxidation assays. The recombinant KatG was assayed regarding its activity on catalase-peroxidase and INH oxidation. Catalase activity was determined by the Patti and Bonet-Maury method, based on the formed color from the reaction of titanium with $\mathrm{H}_{2} \mathrm{O}_{2}$ [17]. The reaction was carried out in $10 \mathrm{mM} \mathrm{K}$-phosphate buffer $\mathrm{pH} 7.0$ with a total volume of $1 \mathrm{ml}$ containing $12.5 \mathrm{mM} \mathrm{H}_{2} \mathrm{O}_{2}$ substrate and $\mathrm{KatG}$ protein. The enzymatic reaction was stopped by the addition of $2.5 \mathrm{ml}$ of titanium reagent, in turn the formed yellow color was observed at $\lambda 410 \mathrm{~nm}$ [17]. One unit of catalase activity was defined as the amount of enzyme decomposing $1 \mathrm{mmol}$ of $\mathrm{H}_{2} \mathrm{O}_{2}$ per min.

Peroxidase activity was determined by reacting of $100 \mu \mathrm{M}$ o-dianisidine in $100 \mathrm{ml}$ of $50 \mathrm{mM}$ potassium buffer ( $\mathrm{pH} 4.5$ ) containing $25 \mathrm{mM}$ tert-butyl hydroperoxide (t-BHP) with $12.5 \mathrm{mM} \mathrm{H}_{2} \mathrm{O}_{2}$. The absorbance of the reaction product, i.e. o-dianisidin quinone diimine was observed at $\lambda 460 \mathrm{~nm}$ $\left(\varepsilon_{460}=11.86 \mathrm{mM}^{-1} \cdot \mathrm{cm}^{-1}\right)$ [13]. One unit of peroxidase activity was defined as the amount of enzyme that catalyzed the formation of one $\mu$ mol product per min at $30{ }^{\circ} \mathrm{C}$.

The activity of kat $G$ on INH oxidation was carried out by the Shoeb method [18]. A mixture 
of $0.65 \mathrm{~g}$ KatG protein in $10 \mathrm{mM}$ phosphate buffer $\mathrm{pH} 7.0$ was reacted with $13.1 \mathrm{mM}$ phenol and $6.25 \mathrm{mM} \mathrm{H}_{2} \mathrm{O}_{2}$ in a total volume of $3 \mathrm{ml}$ at $37{ }^{\circ} \mathrm{C}$ for $7 \mathrm{~min}$, then followed by addition of $2.4 \mathrm{mM}$ INH. The reaction was continued at $37{ }^{\circ} \mathrm{C}$ for $1 \mathrm{~h}$ [18]. The absorbance of the reaction product, i.e. benzo-quinone was monitored at $\lambda 444 \mathrm{~nm}$ $\left(\varepsilon_{444}=0.393 \mathrm{M}^{-1} \cdot \mathrm{cm}^{-1}\right)$. One unit of the activity was defined as the amount of enzyme that catalyzes the formation of benzo-quinone product per min at $37^{\circ} \mathrm{C}$.

Structure alignment. Three-dimensional structure of the mutant KatG protein was generated by SWISS-MODEL, an automated protein homology modeling server, using the known crystal structure of a wild type KatG protein structure (PDB code 1SJ2) as a template. The minimization of the structural model was conducted with Amber 10 [19]. The modeled structure was visualized using PyMOL 1.3 (www.pymol.org). Root mean square deviation of the model was compared to the 1SJ2 structure by Super Pose version 10.

\section{Results and Discussion}

Cloning of $\boldsymbol{k a t} \boldsymbol{G}$ gene from INH-resistant M. tuberculosis strain. The open reading frame (ORF) of kat G gene from L8 Isolate of INH-resistant M. tuberculosis strain was amplified by PCR using FG and RG primers. The $2.2 \mathrm{~kb}$ fragment of PCRproduct then was inserted in pGEM-T vector $(3.0 \mathrm{~kb})$ to construct pGEMT- $k a t G$ recombinant. The recombinant plasmid exhibited two fragments (3.0 and $2.2 \mathrm{~kb}$ ) then it was digested by both EcoRI and NotI restrction enzymes (Fig. 1). The $3.0 \mathrm{~kb}$ fragment corresponded to $\mathrm{pGemT}$ vector, and the $2.2 \mathrm{~kb}$ fragment had the size of the $k a t G$ gene. The $2.2 \mathrm{~kb}$ fragment of L8 isolate carried a mutation, the guanine instead of adenine at position 713 (Fig. 3).

The $k a t G$ gene was then subcloned to pColdIIDNA as expression vector. Insertion of kat G fragment $(2.2 \mathrm{~kb})$ in vector pCold II-DNA $(4.3 \mathrm{~kb})$ yielded a pCold II-katG recombinant $(6.5 \mathrm{~kb})$. Single digestion of the recombinant with $\mathrm{NdeI}$ and $X b a I$ restriction enzymes yielded a DNA fragment $(6.5 \mathrm{~kb})$, respectively, while the digestion with both the enzymes yielded two fragments consisting of 2.2 and $4.3 \mathrm{~kb}$ (Fig. 2). The nucleotides sequences of the kat $G$ gene from the L8 M. tuberculosis isolate showed a substitution of adenine to guanine at position 713 compared to the katG from INH susceptible M. tuberculosis, the H37Rv strain (Fig. 3). The mutation altered the amino acid of KatG protein, the serine instead of asparagine at posistion 238 through in silico translation (Fig. 3).

The KatG expression. To express the katG, the $E$. coli BL21 (DE3) that bring pCold-katG recombinant was grown in LB medium containing amphicilin, then followed the induction of the culture with IPTG. After the cell of E. coli was collected by centrifugation, the cell pellets were lysed to release its extract protein. Analysis of the extract protein in SDS PAGE showed a high intensity of protein band with a molecular mass of $80 \mathrm{kDa}$ that belonged to KatG protein (Fig. 4).

Catalase-peroxidase activities of mutant KatG $_{\text {Asn238Ser }}$. The kinetic properties of catalaseperoxidase of mutant $\mathrm{KatG}_{\text {Asn238Ser }}$ and wild type had been determined, i.e. $K_{\mathrm{M}}, K_{\text {cat }}$ and $K_{\text {cat }} / K_{\mathrm{M}}$. The mutant $\mathrm{KatG}_{\mathrm{Asn} 238 \mathrm{Ser}}$ exhibited the $K_{\text {cat }} / K_{\mathrm{M}}$ value for catalase and peroxidase lower than KatGwt. The $K_{\text {cat }} / K_{\mathrm{M}}$ value mean as the catalytic efficiency of enzyme. The high $K_{\text {cat }} / K_{\mathrm{M}}$ suggested that an enzyme could bind its substrate effectively and decompose its substrate into a product well, and vice versa. KatGwt has $K_{\text {cat }} / K_{\mathrm{M}}$ value as $8.62 \times 10^{4} \mathrm{M}^{-1} \cdot \mathrm{S}^{-1}$ for catalase and $1.99 \times 10^{5} \mathrm{M}^{-1} \cdot \mathrm{S}^{-1}$ for peroxidase. Meanwhile $\mathrm{KatG}_{\text {Asn238Ser }}$ mutants have a low $K_{\text {cat }} / K_{\mathrm{M}}$ value, i.e. $5.12 \times 10^{4} \mathrm{M}^{-1} \cdot \mathrm{S}^{-1}$ for catalase and $0.96 \times 10^{5} \mathrm{M}^{-1} \cdot \mathrm{S}^{-1}$ for peroxidase (Table 2). In addition to the kinetic properties, the mutant $\mathrm{KatG}_{\mathrm{Asn} 238 \mathrm{Ser}}$ took also a declining activity to oxidize INH. The mutant $\mathrm{KatG}_{\mathrm{Asn} 238 \mathrm{Ser}}$ activity in oxidation of isoniazid remained $42.5 \%$ from that of KatGwt (Fig. 5).

Structural Model of mutant $\mathrm{KatG}_{\text {Asn238Ser }}$. Structure modeling of $\mathrm{KatG}_{\text {Asn238Ser }}$ was done to know the effect of amino acid substitution in the mutant protein. Superposition of $\mathrm{C} \alpha$ framework of the mutant model with the KatGwt structure exhibited root mean square deviations (RMSD) of 0.073. This result showed that The mutant $\mathrm{KatG}_{\mathrm{Asn238Ser}}$ shared similiar structure with KatGwt of M. tuberculosis H37Rv. Moreover, the amino acid substitution of Asn238Ser found in the mutant KatG L8 eliminate the salt bridge interaction around the substrate binding site, which connects between the amine group in side chain of Asn238 residue with the carboxyl group of Glu233 in KatGwt (Fig. 6).

$\mathrm{KatG}$ is the only enzyme in M. tuberculosis that could generate isoniazid susceptibility. Therefore it plays a central role in the development of at least one type of isoniazid resistance [20]. Mutations in $k a t G$ are often associated with INH resistance. A substitution of adenine to guanine at position 713 in 


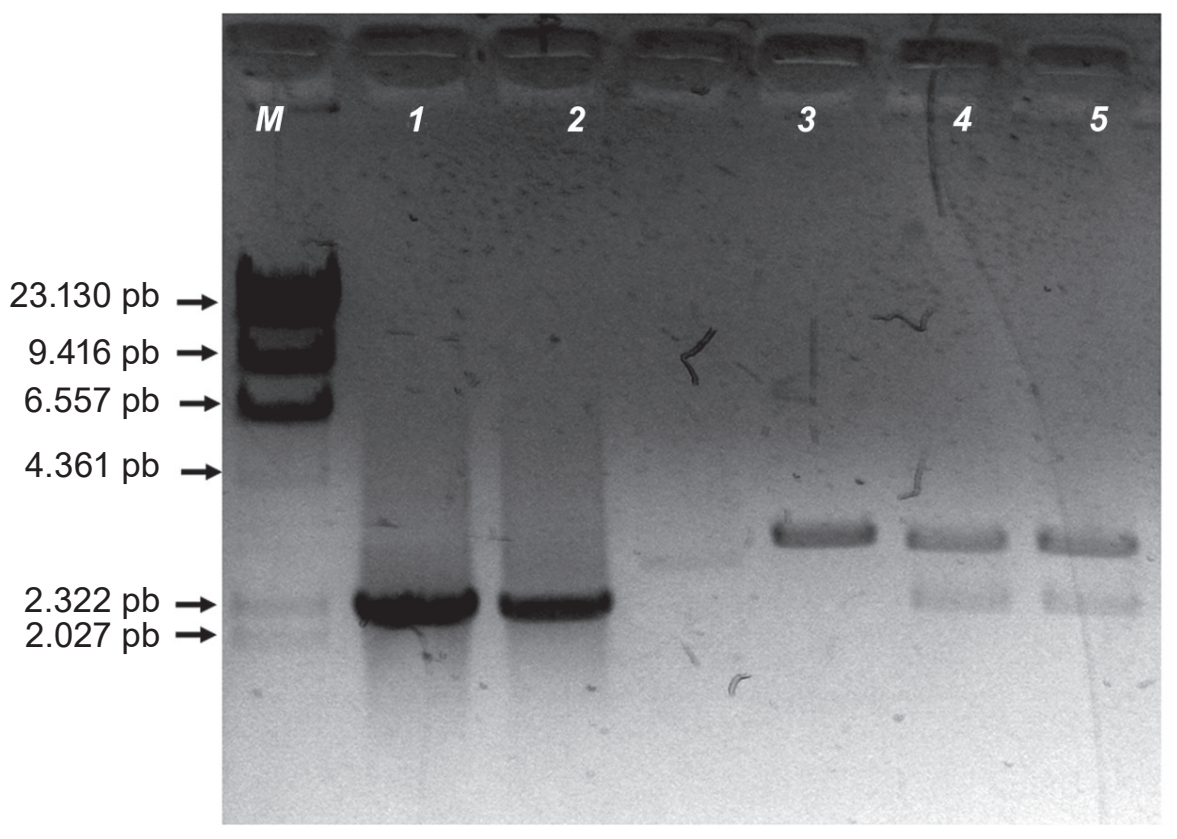

Fig. 1. The restriction map of $p$ GemT-katG recombinat. Marker DNA $\lambda /$ HindIII (M); the $2.2 \mathrm{~kb}$ fragment of PCRproduct from L8 and H37Rv isolate (1 and 2); The purifykatG (3); the pGemT-katG pGemT-katG (L8 and H37Rv) which digested by EcoRI and NotI (4 and 5). Each digestion resulted two fragmens at $3.0 \mathrm{~kb}$ and $2.2 \mathrm{~kb}$. The 3.0 fragment correspond to $p G e m T$ vector, then the $2.2 \mathrm{~kb}$ fragment correspond to the $\mathrm{kat} G$ gene

$k a t G$ gene that correspond to Asn238Ser replacement was found in the L8 clinical isolate which had a resistance level to INH at $1 \mu \mathrm{g} / \mathrm{ml}$. Minimal inhibitor concentration (MIC) of INH for growing $M$. tuberculosis has been reported as 0.02 to $0.06 \mu \mathrm{g} / \mathrm{ml}[3]$. The INH resistance is classified as a low level for MIC value $<1 \mu \mathrm{g} / \mathrm{ml}$, and a high level for MIC value $\geq 1 \mu \mathrm{g} / \mathrm{ml}$ [21]. Many papers showed that the level of INH resistance of clinical isolates of $M$. tuberculosis are not directly correlated with the number of mutations in $k a t G$. There are many clinical isolates resistant to INH at low level, having multiple mutations in $\mathrm{kat} G$, and vice versa, single mutation is connected with high resistance to INH [5, 21, 22].

Direct relationship between mutation in $\mathrm{kat} G$ with INH resistance phenotype is still insufficient to understand the emergence of INH resistance in clinical isolates, because the mutation events might connect with other biological traits. As confirmation that the substitution Asn238Ser connected with INH resistance in clinical isolate of $\mathrm{L} 8$, it was determined the activities of catalase-peroxidase and INH oxidation by the mutant.

The mutant $\mathrm{KatG}_{\mathrm{Asn} 238 \mathrm{Ser}}$ of the L8 isolate exhibited lower catalase and peroxidase activity than that of KatGwt. The mutant has a binding affinity

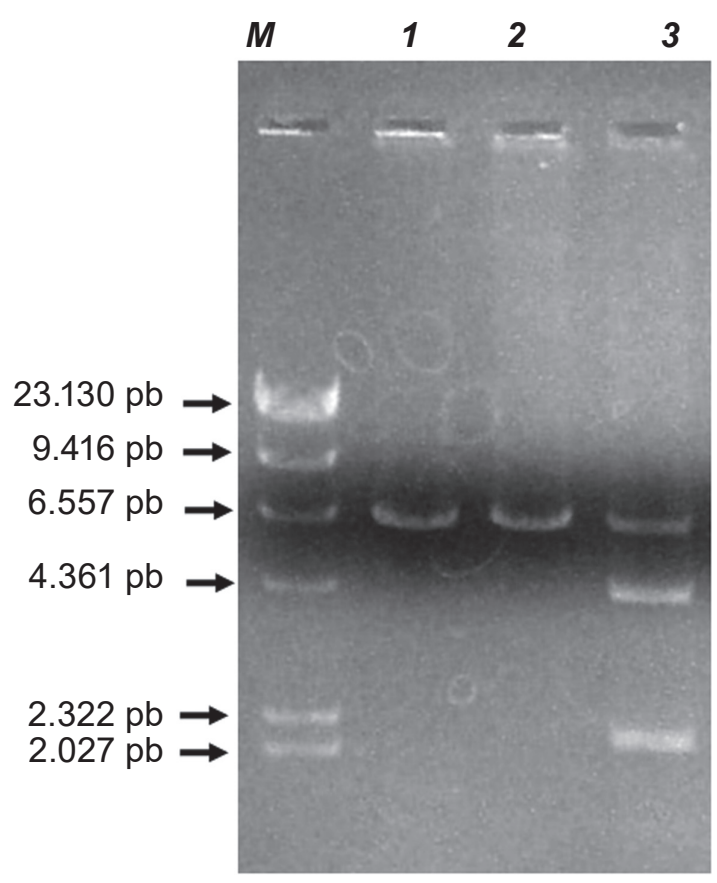

Fig. 2. The restriction map of $p$ Cold II-kat G recombinant. Marker DNA $\lambda$ /HindIII (M), pCold II-DNA/ XbaI (1), pCold II-katG/NdeI (2), pCold II-katG/ $\mathrm{NdeI}+\mathrm{XbaI}$ (3). Dygestion of the recombinant with both the enzymes yielded two fragments consisting of 2.2 and $4.3 \mathrm{~kb}$ 


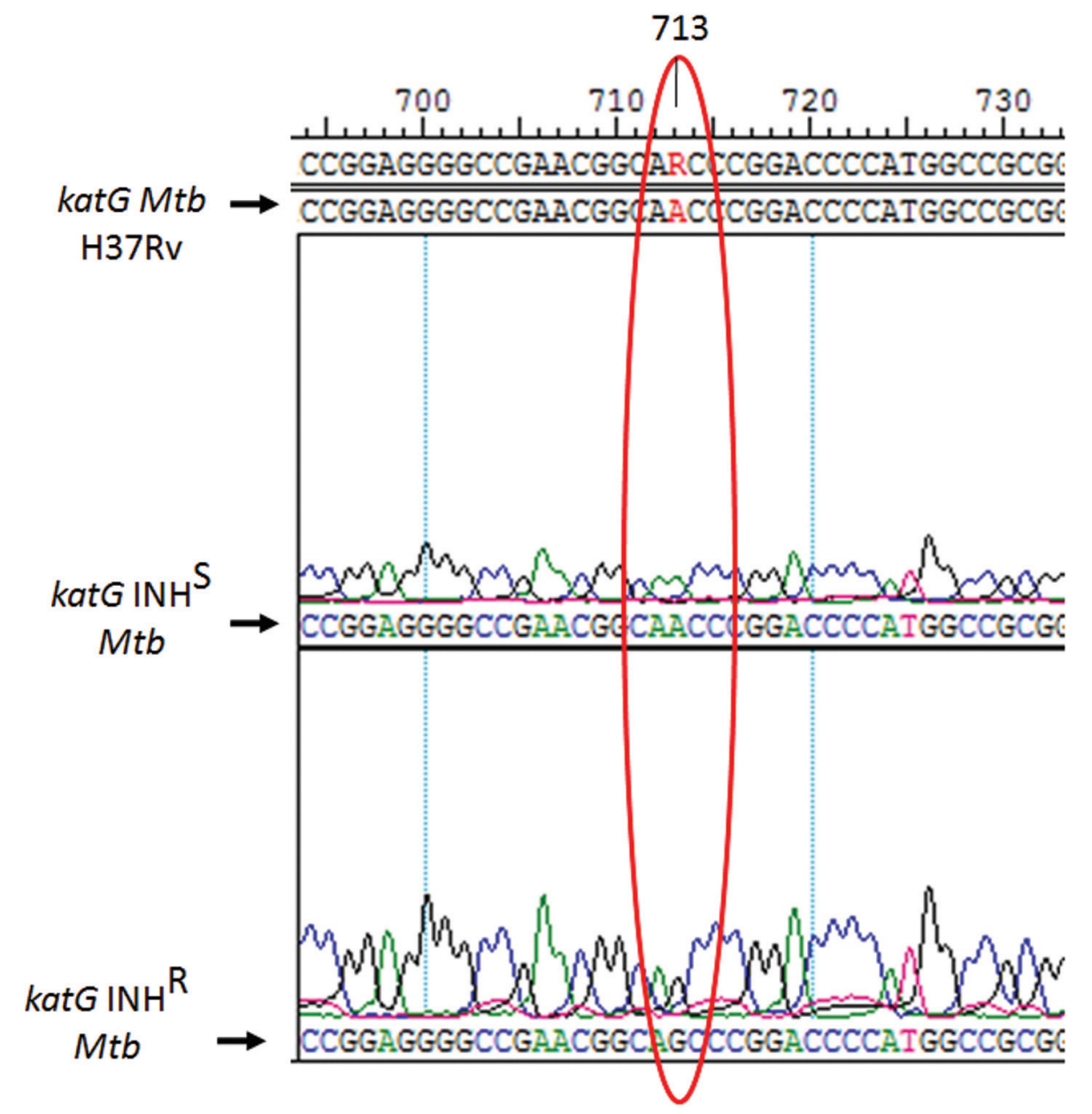

Fig. 3. Nucleotides alignment of the katG of INH resistant M. tuberculosis strain (L8) againts the kat G from INH sensitive strain (H37Rv) and GenBank. Comparing with H37Rv and genbank katG, The L8 katG exhibited a varian nucleotide at position 713, guanine instead of adenine, then substituted Asn with Ser at position 238. Mutation is marked with a red oval

to the substrate is lower than the KatGwt, because it has a value of $K_{\mathrm{M}}$ for each catalase and peroxidase, 1.4 times higher than KatGwt (Table 2). Substitution Asn 238 Ser reduced $40 \%$ of substrate binding affinity for catalase-peroxidase of the mutant. Comparing with KatGwt, the mutant $\mathrm{KatG}_{\text {Asn238Ser }}$ also displayed a decrease of $K_{\text {cat }}$ value by $17 \%$ for catalase and $32 \%$ for peroxidase. This means that the mutant lost 17 and $32 \%$ ability of catalase and peroxidase respectitively in the converting of substrate into product. The catalytic efficiency that symbolized by $K_{\text {cat }} / K_{\mathrm{M}}$ for the mutant $\mathrm{KatG}_{\mathrm{Asn} 238 \mathrm{Ser}}$ decreased by $41 \%$ for catalase and $52 \%$ for peroxidase activity (Table 2). The mutant $\mathrm{KatG}_{\mathrm{Asn238Ser}}$ decreased in both the binding affinity and the converting activity of subtrate into product. Several papers reported that the catalase-peroxidase activity among variants of katG were not correlated with the resistance level of INH $[11,12]$. This can be triggered due to the measurement of enzyme activity in vitro, but it is connected directly with INH resistance phenotype which is actually derived from the in vivo process.

The INH oxidation test of $\mathrm{KatG}_{\text {Asn238Ser }}$ showed that the mutant lost $62 \%$ of the activity compared with that of KatGwt (Table 2). The Asn238Ser modification in KatG of INH resistant isolate (L8) is connected with the decline in the activity of catalase-peroxidase and INH oxidation of the protein. Decreasing of catalytic efficiency $\left(K_{\mathrm{cat}} / K_{\mathrm{M}}\right)$ of mutan $\mathrm{KatG}_{\text {Asn238Ser }}$ as $41 \%$ for catalase and $52 \%$ for peroxidase accompanied the reduction of $62 \%$ in INH oxidation activity of the mutant. The decline of INH activation in many variants of $\mathrm{KatG}$, i.e. Ala110Val, Asp735Ala, Ala139Pro, Ser315Asn, Leu619Pro, and 


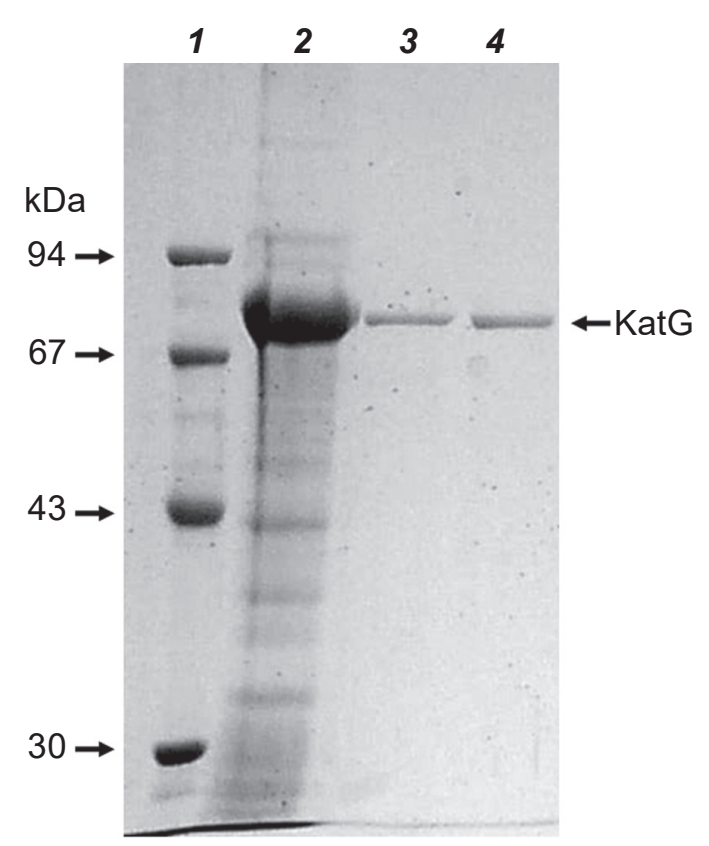

Fig. 4. Electrophoregram of KatG protein in SDS PAGE. Protein marker (1), crude extract of KatG (2), purify product of L8 and H37Rv KatG (3 and 4). The KatG protein was eluted by $100 \mathrm{mM}$ imidazole buffer

Leu634Phe have exhibited a highly correlated with the change level of catalase-peroxidase activity for the mutants [23].

The catalytic function of KatG is carried out effectively by amino acid residues in the active site, i.e. Arg-104, Trp-107 and His-108 residues in the distal pocket, and His270, Trp321 and Asp381 residues in the proximal pocket. INH binds to KatG via interacting with amino acids in the distal pocket. Other residues such as Val230, Asn231, Pro232 and Ser315 have been reported to be involved in interacting with INH [24-26]. The stability in the active site environ-

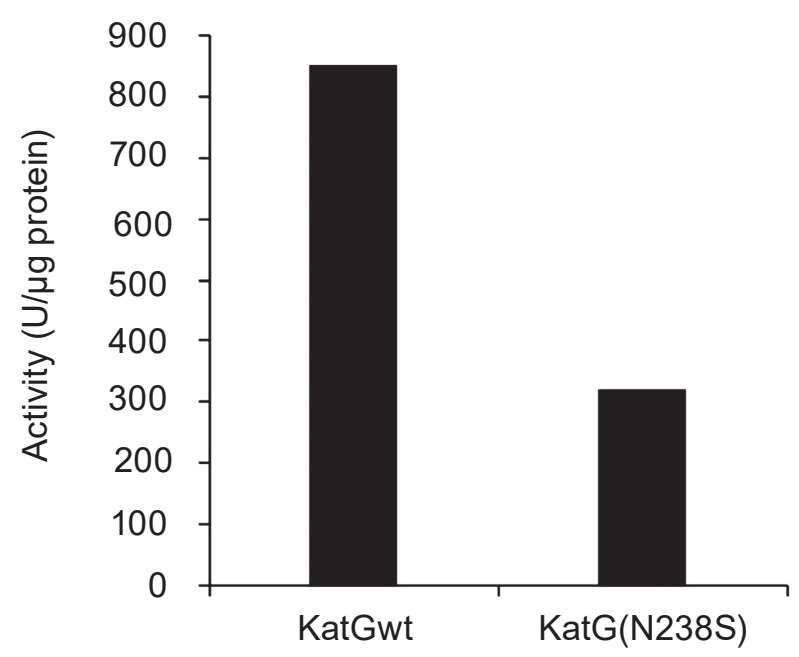

Fig. 5. The INH oxidation activity of wild type and mutant KatG

ment of KatG is required to support the INH activation by the protein.

The failure role of KatG in the INH activating has been shown in detail by the mutant $\mathrm{KatG}_{\text {Ser315Thr }}$ $[12,13,27]$. The Ser315Thr substitution in KatG impacts on the shifting of substrate binding channel from 6.0 to $4.7 \AA$ [27]. Consequently the mutant failed to bind the INH, and subsequently decreased 160 times in the INH activation compared with KatGwt [14].

By using a structure model, the basis of a decrease in the catalytic efficiency for catalase-peroxidase and INH oxidation activity in the mutant $\mathrm{KatG}_{\text {Asn238Ser }}$ was described. In the KatGwt structure, the amino acid 238 is put closely to the substrate binding site, i.e. Asn137, Val230, Asn231, Pro232 and Ser315 residues. It is found that Asn231 residue makes hydrogen bond with Glu233 and Van Der Walls interaction with Asn236. These interactions

Table 2. Kinetic parameters of catalase-peroxidase of KatGwt and $\mathrm{KatG}_{\text {Asn238Ser }}$

\begin{tabular}{l|c|c|c|c}
\hline \multirow{2}{*}{ Activity } & \multirow{2}{*}{ Isolate } & \multicolumn{3}{c}{ Kinetic parameters } \\
\cline { 3 - 5 } & & $K_{\text {cat }}\left(\mathrm{S}^{-1}\right)$ & $K_{\mathrm{M}}(\mathrm{mM})$ & $K_{\text {cat }} / K_{\mathrm{M}}\left(\mathrm{M}^{-1} \cdot \mathrm{S}^{-1}\right)$ \\
\hline Catalase & & & & \\
Wild type KatG & $\mathrm{H} 37 \mathrm{Rv}$ & 272.3 & 3.16 & $8.62 \times 10^{4}$ \\
KatG (Asn238Ser) & $\mathrm{L} 8$ & 227.5 & 4.44 & $5.12 \times 10^{4}$ \\
Peroxidase & & & & \\
Wild type KatG & $\mathrm{H} 37 \mathrm{Rv}$ & 49.0 & 0.25 & $1.99 \times 10^{5}$ \\
KatG (Asn238Ser) & $\mathrm{L} 8$ & 33.3 & 0.35 & $0.96 \times 10^{5}$ \\
\hline
\end{tabular}




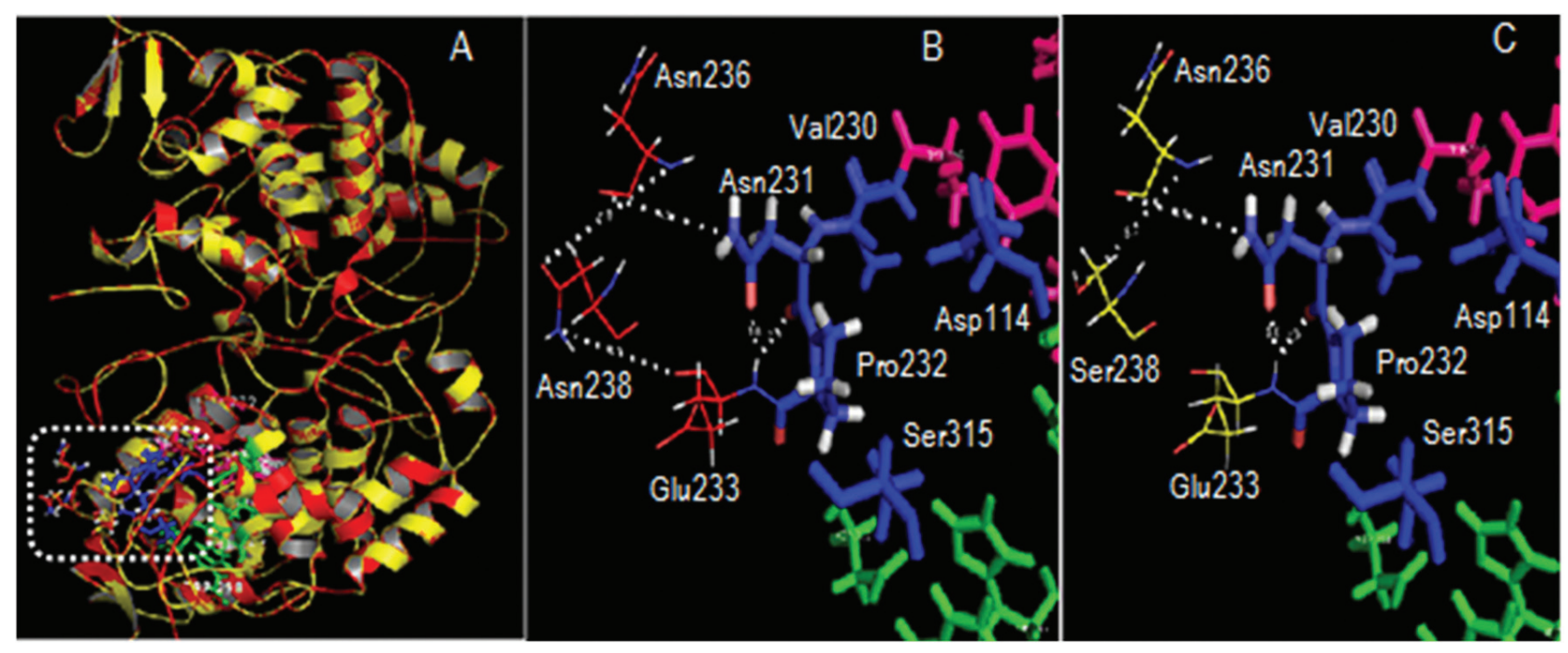

Fig. 6. Illustration of Asn238Ser substitution effect in KatG L8. Superposition of mutant KatG structure (L8) (yellow) to the KatGwt (red) (A). The blue rod-shaped amino acids represented the residues for subtrate binding; green rod-shaped amino acids represented catalytic residues, and magenta are the residue for cross links. In the KatGwt, the Asn238 stabilized the active site environment through linkage to the Glu233 and Asn236 (B). In the mutant KatG L8, the Ser238 residue could not make interaction with Glu233

are stabilized by the presence of salt bridge which connects between the amine group in side chain of Asn238 residue with the carboxyl group of Glu233 in KatGwt (Fig. 6). This salt bridge was lost due to modification of Asn238Ser in the mutant KatG L8. The lost of the salt bridge created unfavorable for enzyme activities, then in turn it emerged the INH resistance in the L8 isolate of M. tuberculosis. The model analysis of $\mathrm{KatG}_{\mathrm{Asn} 238 \mathrm{Ser}}$ should be further confirmed by a real crystal structure of the mutant.

Conflicts of interest. All authors declare that there is no conflict of interest.

\section{Acknowledgements}

A partial funding of this research was supported by DIPA Secretariat of Research and Development Agency, The Ministry of Health, Republic of Indonesia, Number: 0682/034-11.1.01/00/2011. We also thank Prof. Shigeru Shigeoka, PhD., Plant Molecular Physiology Lab, Dept of Advance Bioscience, Kinki University, Japan for giving pCold II-DNA plasmid and laboratory support for this research. 


\section{МУТАЦІЯ $k a t G$ У КЛІНІЧНОМУ ІЗОЛЯТ Mycobacterium tuberculosis: \\ ВПЛИВ НА КАТАЛАЗУ- ПЕРОКСИДАЗУ, ЩО АКТИВУЄ ІЗОНІАЗИД}

Purkan ${ }^{1}$ Ihsanawati ${ }^{2}$, D. Natalia ${ }^{2}$, Y. M. Syah ${ }^{2}$, D. S. Retnoningrum ${ }^{3}$, H. S. Kusuma ${ }^{4}$

${ }^{1}$ Biochemistry Research Division, Department of Chemistry, Faculty of Sciences and Technology,

Airlangga University; Surabaya, Indonesia; e-mail: purkan@fst.unair.ac.id;

${ }^{2}$ Biochemistry Research Division, Faculty of

Mathematics and Natural Sciences, Bandung

Institute of Technology, Bandung, Indonesia;

${ }^{3}$ School of Pharmacy, Bandung Institute of Technology, Bandung, Indonesia;

${ }^{4}$ Department of Chemical Engineering, Institute

Teknologi Sepuluh Nopember, Surabaya, Indonesia; e-mail: heriseptyakusuma@gmail.com

Мутації в гені katG часто пов'язані i3 резистентністю штаму Mycobacterium tuberculosis до ізоніазиду. Дослідження проведено з метою виявлення мутації kat $G$ в клінічному ізоляті (L8) 3 M. tuberculosis, стійкими до ізоніазиду за концентрації 1 мкг/мл. У роботі охарактеризовано каталазу-пероксидазу $\mathrm{KatG}$ L8 і проведено вивчення структури протеїну 3 метою глибше зрозуміти процес активації препарату і механізм резистентності до нього $M$. tuberculosis. Ген katG був клонований і експресований в Escherichia coli, вивчено властивості каталази-пероксидази KatG. Проведено моделювання структури протеїну для з'ясування причин зміни ензиматичної активності. Встановлено заміщення каталази-пероксидази А713G, що відповідає заміні Asn238Ser в L8 katG. Модифікація Asn238Ser у протеїні L8 KatG призводила до зниження активності каталази-пероксидази і окислення ізоніазиду. Каталітична ефективність $\left(K_{\text {саt }} / K_{\mathrm{M}}\right)$ мутантного $\mathrm{KatG}_{\text {Asn238Ser }}$ зменшувалась для каталази і пероксидази до 41 i $52 \%$ відповідно. Мутант $\mathrm{KatG}_{\mathrm{Asn} 238 \mathrm{Ser}}$ також знижував окислення ізоніазиду на $62 \%$ порівняно $з$ диким типом KatG (KatGwt). Показано, що мутація Asn238Ser може призвести до нестабільності в сполучній ділянці KatG через вилучення електростатичного зв'язку, що з'єднує аміногрупу Asn238 із карбоксильною групою Glu233, яка представлена в KatGwt. Втрата електростатичного зв'язку в місці зв'язування субстрату в му- танта $\mathrm{KatG}_{\mathrm{Asn} 238 \mathrm{Ser}}$ Знижує активність ензимів, що, в свою чергу, зумовлює резистентність M. tuberculosis до ізоніазиду в ізоляті L8.

К л ючов в слова: Mycobacterium tuberculosis, резистентність до ізоніазиду, katG, каталаза-пероксидаза.

МУТАЦИЯ katG В КЛИНИЧЕСКОМ

ИЗОЛЯТЕ Mycobacterium tuberculosis:

ВЛИЯНИЕ НА КАТАЛАЗУ-

ПЕРОКСИДАЗУ, АКТИВИРУЮЩУЮ ИЗОНИАЗИД

Purkan , Ihsanawati ${ }^{2}$, D. Natalia 2 , Y. M. Syah ${ }^{2}$, D. S. Retnoningrum ${ }^{3}$, H. S. Kusuma ${ }^{4}$

${ }^{1}$ Biochemistry Research Division, Department of Chemistry, Faculty of Sciences and Technology, Airlangga University; Surabaya, Indonesia; e-mail: purkan@fst.unair.ac.id;

${ }^{2}$ Biochemistry Research Division, Faculty of Mathematics and Natural Sciences, Bandung Institute of Technology, Bandung, Indonesia; ${ }^{3}$ School of Pharmacy, Bandung Institute of Technology, Bandung, Indonesia;

${ }^{4}$ Department of Chemical Engineering, Institute Teknologi Sepuluh Nopember, Surabaya, Indonesia; e-mail: heriseptyakusuma@gmail.com

Мутации в гене katG часто связаны с резистентностью штамма Mycobacterium tuberculosis к изониазиду. Это исследование проведено для определения мутации $\mathrm{kat} G$ в клиническом изоляте (L8) с M. tuberculosis, устойчивыми к изониазиду при концентрации 1 мкг/мл. В работе охарактеризована каталаза-пероксидаза $\mathrm{KatG}$ L8 и выполнены первоначальные структурные исследования протеина с целью более полного понимания процесса активации препарата и механизма резистентности к нему M. tuberculosis. Ген $k a t G$ был клонирован и экспрессирован в Escherichia coli, затем изучены свойства каталазы-пероксидазы KatG. Проведено моделирование структуры протеина для выяснения причин изменения энзиматической активности. Установлено замещение каталазы-пероксидазы A713G, что соответствует замене Asn238Ser в L8 katG. Модификация Asn238Ser в протеине L8 KatG приводила к снижению активности каталазы-пероксидазы и окисления изониазида. Каталитическая эффективность $\left(K_{\mathrm{cat}} / K_{\mathrm{M}}\right)$ мутантного $\mathrm{KatG}_{\mathrm{Asn238Ser}}$ уменьшалась для каталазы 
и пероксидазы до 41 и 52\% соответственно. Мутант $\mathrm{KatG}_{\mathrm{Asn238Ser}}$ также снижал окисление изониазида на $62 \%$, по сравнению с диким типом KatG (KatGwt). Показано, что мутация Asn238Ser может привести к нестабильности в связывающем участке KatG из-за удаления электростатической связи, соединяющей аминогруппу Asn238 с карбоксильной группой Glu233, которая представлена в KatGwt. Потеря электростатического взаимодействия в месте связывания субстрата в мутанте $\mathrm{KatG}_{\text {Asn238Ser }}$ снижает активность энзимов, что, в свою очередь, обусловливает резистентность к изониазиду M. tuberculosis в изоляте L8.

Ключе вы е слова с Mycobacterium tuberculosis, резистентность к изониазиду, kat $G$, каталаза-пероксидаза.

\section{References}

1. Anonymous. Tuberculosis. https://www.expat. or.id/medical/tuberculosis. Retrieved 2014-1125.

2. Purkan, Ma'ruf MJA, Retnowati W, Baktir A, Puspaningsih NNT. Mutation in pncA and distortion in PZase model structure as a basis of pyrazinamide resistance in Mycobacterium tuberculosis. JChem Pharm Res. 2015; 7(1): 312318.

3. Cardoso RF, Cooksey RC, Morlock GP, Barco P, Cecon L, Forestiero F, Leite CQ, Sato DN, Shikama Mde L, Mamizuka EM, Hirata RD, Hirata MH. Screening and characterization of mutations in isoniazid-resistant Mycobacterium tuberculosis isolates obtained in Brazil. Antimicrob Agents Chemother. 2004; 48(9): 3373-3381.

4. Pretorius GS, van Helden PD, Sirgel F, Eisenach KD, Victor TC. Mutations in katG gene sequences in isoniazid-resistant clinical isolates of Mycobacterium tuberculosis are rare. Antimicrob Agents Chemother. 1995; 39(10): 2276-2281.

5. Purkan, Ihsanawati, Syah Y, Retnoningrum D, Noer A, Shigeoka S, Natalia D. Novel mutations in $k a t G$ gene of a clinical isolate of isoniazidresistant Mycobacterium tuberculosis. Biologia. 2012; 67(1): 41-47.

6. Zhang Y, Dhandayuthapani S, Deretic V. Molecular basis for the exquisite sensitivity of Mycobacterium tuberculosis to isoniazid. Proc Natl Acad Sci USA. 1996; 93(23): 13212-13216.
7. Heym B, Saint-Joanis B, Cole ST. The molecular basis of isoniazid resistance in Mycobacterium tuberculosis. Tuber Lung Dis. 1999; 79(4): 267271.

8. Rouse DA, DeVito JA, Li Z, Byer H, Morris SL. Site-directed mutagenesis of the katG gene of Mycobacterium tuberculosis: effects on catalaseperoxidase activities and isoniazid resistance. Mol Microbiol. 1996; 22(3): 583-592.

9. Atalay F, Akar N, Ernam Turgut D, Aysev D, Ergün P, Erdoğan Y. Catalase-Peroxidase Gene (KatG) Deletion in Isoniazid Resistant Strains of Mycobacterium tuberculosis. T Klin J Med Sci. 2004; 24(3): 243-246.

10. $\mathrm{Yu} \mathrm{S}$, Chouchane S, Magliozzo RS. Characterization of the W321F mutant of Mycobacterium tuberculosis catalaseperoxidase KatG. Protein Sci. 2002; 11(1): 5864.

11. Ghiladi RA, Medzihradszky KF, Rusnak FM, Ortiz de Montellano PR. Correlation between isoniazid resistance and superoxide reactivity in Mycobacterium tuberculosis KatG. J Am Chem Soc. 2005; 127(38): 13428-13442.

12. Cade CE, Dlouhy AC, Medzihradszky KF, SalasCastillo SP, Ghiladi RA. Isoniazid-resistance conferring mutations in Mycobacterium tuberculosis KatG: catalase, peroxidase, and INH-NADH adduct formation activities. Protein Sci. 2010; 19(3): 458-474.

13. Wengenack NL, Lane BD, Hill PJ, Uhl JR, Lukat-Rodgers GS, Hall L, Roberts GD, Cockerill FR 3rd, Brennan PJ, Rodgers KR, Belisle JT, Rusnak F. Purification and characterization of Mycobacterium tuberculosis KatG, KatG(S315T), and Mycobacterium bovis KatG(R463L). Protein Expr Purif. 2004; 36(2): 232-243.

14. Kapetanaki SM, Zhao X, Yu S, Magliozzo RS, Schelvis JP. Modification of the active site of Mycobacterium tuberculosis KatG after disruption of the Met-Tyr-Trp cross-linked adduct. J Inorg Biochem. 2007; 101(3): 422-433.

15. Noviana H, Nurachman Z, Ramdani M, Noer AS. Multiplex PCR for rapid detection of rifampin and isoniazid resistance in Mycobacterium tuberculosis isolated from Bandung, Indonesia. Microbiology (Indonesia). 2007; 1(3): 114-118.

16. Sambrook JF, Maniatis T. Molecular Cloning Laboratory Manual. $2^{\text {nd }}$ ed. USA: Cold Spring Harbour Laboratory Press; 1989. 
17. Patti F, Bonet-Maury P. Colorimetric method for determination of catalase. Bull Soc Chim Biol (Paris). 1953; 35(10): 1177-1180.

18. Shoeb HA, Bowman BU Jr, Ottolenghi AC, Merola AJ. Evidence for the generation of active oxygen by isoniazid treatment of extracts of Mycobacterium tuberculosis H37Ra. Antimicrob Agents Chemother. 1985; 27(3): 404-407.

19. Case DA, Darden TA, Cheatham TE, Simmerling CL, Wang J, Duke RE, et al. AMBER 9. San Fancisco: University of California; 2006.

20. Johnsson K, Froland WA, Schultz PG. Overexpression, purification, and characterization of the catalase-peroxidase KatG from Mycobacterium tuberculosis. J Biol Chem. 1997; 272(5): 2834-2840.

21. Rahimi MK, Bostanabad ZS, Adimi P, Shekarabei M, Habibollah M, Shirmohammadi F, Bigdeli Kh, Faraji A, Delalat B, Tayebi Z, Masoumi M, Jabbarzadeh E, Pourazar Sh, Titov LP. Multiple-mutations in the $\mathrm{katG}$ encoding catalase proxidase in isoniazid resistant Mycobacterium tuberculosis isolates correlate with high-level of resistance in patients with active pulmonary tuberculosis in Iran. J Microbiol Antimicrob. 2009; 1(1): 1-8.

22. Ando H, Kondo Y, Suetake T, Toyota E, Kato S, Mori T, Kirikae T. Identification of katG mutations associated with high-level isoniazid resistance in Mycobacterium tuberculosis. Antimicrob Agents Chemother. 2010; 54(5): 1793-1799.
23. Wei CJ, Lei B, Musser JM, Tu SC. Isoniazid activation defects in recombinant Mycobacterium tuberculosis catalase-peroxidase (KatG) mutants evident in InhA inhibitor production. Antimicrob Agents Chemother. 2003; 47(2): 670675.

24. Bertrand T, Eady NA, Jones JN, Jesmin, Nagy JM, Jamart-Grégoire B, Raven EL, Brown KA. Crystal structure of Mycobacterium tuberculosis catalase-peroxidase. J Biol Chem. 2004; 279(37): 38991-38999.

25. Pierattelli R, Banci L, Eady NA, Bodiguel J, Jones JN, Moody PC, Raven EL, JamartGrégoire B, Brown KA. Enzyme-catalyzed mechanism of isoniazid activation in class I and class III peroxidases. J Biol Chem. 2004; 279(37): 39000-39009.

26. Smulevich G, Jakopitsch C, Droghetti E, Obinger C. Probing the structure and bifunctionality of catalase-peroxidase (KatG). J Inorg Biochem. 2006; 100(4): 568-585.

27. Zhao X, Yu H, Yu S, Wang F, Sacchettini JC, Magliozzo RS. Hydrogen peroxide-mediated isoniazid activation catalyzed by Mycobacterium tuberculosis catalase-peroxidase (KatG) and its S315T mutant. Biochemistry. 2006; 45(13): 41314140 .

Received 29.08.2016 